\title{
Normative Violence in Domestic Service: A Study of Exploitation, Status, and Grievability
}

\author{
Rohit Varman ${ }^{1} \cdot$ Per Skålén ${ }^{2} \cdot$ Russell W. Belk ${ }^{3} \cdot$ Himadri Roy Chaudhuri ${ }^{4}$
}

Received: 9 February 2019 / Accepted: 17 January 2020 / Published online: 28 January 2020

(c) The Author(s) 2020

\begin{abstract}
This paper contributes to business ethics by focusing on consumption that is characterized by normative violence. By drawing on the work of Judith Butler this study of kajer lok-a female subaltern group of Indian domestic service providers-and their higher status clients shows how codes of status-based consumption shaped by markets, class, caste, and patriarchy create a social order that reduces kajer lok to "ungreivable" lives. Our study contributes to business ethics by focusing on exploitation and coercion in consumption rather than in production and of woman rather than of men. It adds to consumer research by revealing how social distinctions not only manifest in status contests in which symbolic power is at stake but also may produce violent exploitation and ungrievable lives.
\end{abstract}

Keywords Consumer ethics $\cdot$ Exploitation $\cdot$ Judith butler $\cdot$ Normative violence $\cdot$ Status consumption $\cdot$ Grievability

Business ethics scholars have examined exploitation and coercion of workers casting in high relief working conditions in sweatshops (e.g., Preiss 2014; Snyder 2008, 2010). Although some researchers have found sweatshop working conditions to be morally acceptable (e.g., Powell and Zwolinski 2012; Zwolinski 2007), many others have labeled them as unethical and immoral (Arnold and Bowie 2003; Arnold and Hartman 2006). While these studies have contributed to understanding what constitutes exploitation, coercion, and unethical behavior, there is an under-examination of these

Rohit Varman

r.varman@bham.ac.uk

Per Skålén

per.skalen@kau.se

Russell W. Belk

rbelk@schulich.yorku.ca

Himadri Roy Chaudhuri

himadric@gmail.com

1 Department of Marketing, University of Birmingham, 116 Edgbaston Park Rd, Birmingham B15 2TY, UK

2 Service Research Center, Karlstad Business School, Karlstad University, Universitetsgatan 2, 65188 Karlstad, Sweden

3 Schulich School of Business, Kraft Foods Canada Chair in Marketing, York University, 4700 Keele Street, Toronto, ON M3J 1P3, Canada

4 XLRI, Jamshedpur, India issues in consumption and service contexts. We argue that this oversight of normative violence or violence encoded in consumer/consumption norms has resulted in an inadequate understanding of exploitation and coercion in consumer ethics. Moreover, by primarily focusing on sweatshop workers, there is a neglect of the gendered nature of violent exploitation that is normalized against women service providers in the domestic sphere of consumption. In particular, we draw on a study of female domestic service providers called kajer lok and their service interactions with their higher status clients in Kolkata, India to explain normative violence encoded in status-based consumption that is part of domestic service.

Our study of the normative violence encountered by kajer lok also has implications for the work of consumer researchers on social distinctions and status hierarchies (Allen 2002; Holt 1998; Üstüner and Holt 2010; Üstüner and Thompson 2012; Vikas et al. 2015). Drawing on the work of Bourdieu $(1984,1990)$, these researchers have highlighted the role of symbolic power that stems from "capital of honor and prestige which produces a clientele as much as it is produced by it" (Bourdieu 1990, p. 118). While these consumer researchers have uncovered different aspects of symbolic power in their analyses of social distinctions, there is a relative neglect of how status hierarchies translate into apparatuses of exploitation and violence. Moreover, emphasis on symbolic power overlooks how violent exploitation is normalized through consumption. We offer a corrective 
to this lacuna in consumer ethics by examining how social distinctions are premised upon and contribute to violent exploitation.

We understand violence as the use of force against an individual or the denial of rights of personhood (Galtung 1990) and is an unethical behavior (Gubler et al. 2018). Our attention to normative violence helps to develop an understanding of consumer ethics that attends to how consumer/ consumption norms establish a social order within which violent exploitation is normalized or unfolds as normal without moral compunctions. We draw upon Butler to attend to normative violence, the ethics of grievability, and derealization to understand normalized exploitation of service providers. According to Butler (2009, p. 15) a grievable life means, "a life that can be regarded as a life, and be sustained by that regard. Without grievability, there is no life, or rather, there is something living that is other than life...sustained by no regard, no testimony, and ungrieved when lost." Therefore, grievability allows an individual to gain a subject position and to be regarded as a human. In its absence, we are derealized or made less human and can be inflicted with violence without perceiving any ethical dilemmas and moral condemnation. Butler's (2004a) idea of normative violence suggests that norms can both be violent in themselves and be used to normalize violence against those who are derealized (Joy et al. 2015; Varman et al. 2018).

We find that service interactions are characterized by violence inflicted on kajer lok by their higher status clients as they follow their normatively prescribed codes of consumption without questioning them. By drawing on Butler (2004a, 2009) we cast in sharp relief how the status-based consumption that takes place in domestic service produces ungrievability of service providers. We show that domestic service encodes specific status-based norms of consumption for clients and service providers and constitutes them as consuming/serving subjects with clear boundaries of what is permissible and what is not. In doing so, we add to the literature on status-based consumption, exploitation, and coercion in consumer ethics by identifying the norms of consumption that normalize violence by making lives of kajer lok ungrievable. In the following sections, we elaborate on these issues to broaden our understanding of how violent exploitation unfolds without ethical dilemmas and moral compunctions.

\section{Theoretical Considerations}

Bourdieu's $(1984,1990)$ explains how arbitrary choices and relations in a social space, or a field, get transformed into legitimate relations that help to create widely recognized distinctions and status hierarchies. Bourdieu delves into status hierarchies and questions their taken for granted character as worldviews of a society. Based on this analysis, he develops the idea of symbolic power "that is not perceived as power but as legitimate demands for recognition, deference, obedience, or the services of others" (Swartz 1997, p. 43). According to Bourdieu, status hierarchies go misrecognized as a form of power under the veneer of culture that legitimizes domination by presenting it under the guise of disinterestedness. Therefore, Bourdieu (1990, p. 141) contends, "this mis-recognition, unaware that it produces what it recognizes, does not want to know that what makes the most intrinsic charm of its objects, its charisma, is merely the product of the countless crediting operations through which agents attribute to the object the powers to which they submit." Such a system of power fulfills a political function by creating symbolic violence in which the subordinates accept as legitimate their own condition of domination (Bourdieu 1977). Hence, symbolic power often manifests itself in violence that is, "invisible, unrecognized as such, chosen as much as undergone, that of trust, obligation, personal loyalty... of all virtues honored by the ethic of honor" (Bourdieu 1990, p. 127).

Several writings in consumer research draw upon the work of Bourdieu to offer a nuanced understanding of social distinctions and status hierarchies. Üstüner and Holt (2007) observe that poor women in a Turkish squatter community respond to their subordination by shutting out the dominant ideology, pursuing this dominant consumption pattern, or giving up on both practices and suffering a shattered identity project. In the context of status consumption in the Global South, Üstüner and Holt (2010) show that while low cultural capital consumers are situated within an indigenized field and are influenced by local elites in consumption choices, high cultural capital consumers copy Western consumers and their mythical lifestyles to assert their superiority over subordinate groups. In the same cultural context, Üstüner and Thompson (2012) observe that stratified market encounters feature status struggles and contests of symbolic capital. Further, acceptance of the symbolic power of the elite is reinforced by attempts of subordinate groups to reconfigure their habitus or disposition to match dominant groups. More recently, Vikas et al. (2015) drawing upon the work of Bourdieu show that high castes can lose their positions of domination and symbolic power when they are challenged by the lower castes, who are able to gain access to markets in India.

While Bourdieu's emphasis on symbolic power helps consumer researchers to gain important insights into how social distinctions and status hierarchies are created and reproduced through consumption, there is a neglect of how distinctions enable physical violence and exploitation. Although Bourdieu was conscious that physical violence may be a response to an erosion of the efficacy of symbolic violence (Burawoy 2010), the relationship between symbolic 
power and violent exploitation is largely unexplored in consumer research and consumer ethics. Such a neglect of the ethics of exploitation is also common in Bourdeiusian writings because Bourdieu's analysis of social distinctions does not pay adequate attention to moral aspects (Ignatow 2009; Sayer 2005). On the other hand, several scholars in business ethics have attended to exploitation and coercion in the domain of production. It is these issues of exploitation that we discuss in the next section.

\section{Exploitation and Coercion}

Exploitation has been defined in multiple ways. In an important work, sample (2003) contends that exploitation involves taking advantage of somebody. For Sample injustice and lack of respect are central to the idea of exploitation. While differentiating between harmful and mutually advantageous exploitation, Wertheimer (1996, p. 207 emphasis in original) suggests, "an exploitative transaction is one in which A takes unfair advantage of B. A engages in harmful exploitation when A gains by an action or transaction that is harmful to B." Drawing upon the work of Wertheimer, Valdman (2008, p. 568) adds that it is necessary to attend to wrongful exploitation as somebody gaining unfairly or excessively from a transaction with another. Accordingly, Wertheimer fails to pay attention to exploitee's state of desperation that is central to wrongful exploitation.

A distinction can be made between exploitative systems and exploitative practices. The fact that slavery, feudalism, and capitalism are exploitative systems does not necessarily mean that they are comprised solely of exploitative practices. For example, Fontaine (2015) finds evidence of benign practices within the structurally exploitative system of European Feudalism and Hilliard (2014) documents instances of benign treatment of slaves during the antebellum American South. Despite such exceptions, the point is that within exploitative systems there is a normative sanction for exploitative practices as well as a tendency for them to become common practice. Thus there is not only the injury of specific exploitative practices, but also a normative environment that accepts such practices as normal.

In business ethics, Arnold and his colleagues have documented many accounts of exploitation of sweatshop labor and pointed to several deficiencies of multinational corporations in improving working conditions (e.g., Arnold and Bowie 2003; Arnold and Bowie 2007; Arnold and Hartman 2003; Arnold and Hartman 2006). In response, some researchers in the context of sweatshops make the nonworseness claim and have argued that in certain instances exploitees volunteer their services because of absence of better alternatives (Powell and Zwolinski 2012; Zwolinski 2007). Accordingly, workers are likely to be worse off in the absence of employment opportunities and the choices exercised by sweatshop workers express their autonomy, and negate or mitigate the moral claims against such work. Such defense of sweatshop labor is based on the moral permissibility of exploitation (Snyder 2010). This moral permissibility draws upon claims of benefits to the exploitee or sufficient hardship if the economic relationship was prevented.

Snyder $(2008,2010)$ adds to the debate by differentiating between need and fairness exploitation. He suggests that the concern of fairness exploitation with equal distribution of benefits may not necessarily withstand moral scrutiny. Instead, he makes a case for need exploitation which he considers as morally sound and grounded in the specification of the duty of beneficence. Preiss (2014) makes an intervention in this debate on moral permissibility by pointing to how structural, historical, and institutional conditions that create exploitation are often overlooked by defenders of sweatshop labor such as Powell and Zwolinski (2012). In this research, we limit our attention to harmful or wrongful exploitation by clients toward domestic service providers or kajer lok and on the resulting vulnerable state of kajer lok. Moreover, we pay attention to violence as a form of coercion. Wertheimer (1996, p. 256) reads coercion as "rendering B's consent unfree or involuntary.” Wolff (1999) insightfully points out that coercion proceeds by first creating vulnerability and then exploiting it. In a way, coercion generates exploitable circumstances.

Despite extensive theorization of exploitation and coercion in business ethics, there is limited attention to how violent exploitation is normalized. It is important to understand normalization of violent exploitation because it not only helps to locate more exact contours of exploitation but also casts in high relief why it does not produce ethical dilemmas and moral compunctions. To understand normalization of violent exploitation, we turn to the literature on the sociology of domestic work and writings of Judith Butler on normative violence.

\section{Domestic Service and the Status Hierarchy of Consuming/Serving Subjects}

Domestic service is an age-old tradition in India that has created a culture of servitude. Ray and Qayum $(2009$, p. 3) observe that "a culture of servitude is one in which social relations of domination/subordination, ordination, dependency, and inequality are normalized and permeate both the domestic and public spheres." For a long period, low caste serfs and women have performed domestic work in India (Lokesh 2015). The term domestic service is difficult to define; so are the duties of domestic service providers in India. In common parlance, a domestic service provider is defined as a person who is engaged on a part-time or fulltime basis in domestic service for remuneration payable in cash. Domestic work includes all household tasks such as 
cleaning of clothes, dishes, and homes, cooking, child care, nursing the elderly, and purchase of groceries. There is no uniformity in the wage that is paid, the hours of work, or the number of working hours and days.

There has been an increase in demand for domestic service providers in urban India (Jain 2015). The Government of India's statistics reveal that there are 4.2 million domestic service providers in the country. The International Labor Organization (2015) considers this an under-estimation and points to the possibility of the existence of 90 million workers in the domestic sector. The increase in the demand of domestic services can be related to the emergence of dual careers as a new family norm. By hiring someone to take care of the household tasks, the double burden on middleclass women is reduced without disturbing the traditional patriarchal system (Jain 2015). Despite the rising demand for domestic work, wages continue to be pegged at abysmally low levels and represent one of the most poorly paid jobs in the informal sector of the economy. According to the National Skill Development Centre of the Government of India, a domestic service provider cannot expect to earn more than INR 6000 (USD 100) a month, and a large portion earns around INR 1000 (USD 15) a month.

Patriarchy inclines to feminization of domestic service, something that was less true in an earlier era of life-long male servants (Ray and Qayum 2009). Feminization often translates into devaluation of service, poor work conditions, and jobs that are monotonous (Dutt 2018; Harju 2017). Domestic service work constitutes the final refuge of the female workforce, especially for poor and uneducated women (Chakravarty and Chakravarty 2008; Dickey 2000a; Mitra 2005). Several studies of women working in domestic service point to conditions of extreme poverty and deprivation (e.g., Chen 2012; Unni 2001). Raghuram (2001) suggests that women work as domestic service providers because the work is performed within the house and so remains within the private domain that is associated with women. In another study, Raghuram (2005) observes that domestic work in India is regulated through feudal relations based on incomplete contractualization, with no effort by the State to protect the interests of service providers. Ray and Qayum (2009) report that efforts to form unions by kajer lok has failed but that there exist groups of kajer lok with informal leaders that serves as spokespersons for their collective concerns. They argue that "These leaders play an important role when it comes to blacklisting bad employers, obtaining employer help for particular servants in need, or indeed, withdrawing support from a particular servant after a falling out or because that person has come to be considered problematic by the group" (p. 74). However, such strengthening of collective bargaining power are scarce. The general picture is that kajer lok have a limited ability to voice their collective concerns (Dickey 2016; Ray and
Qayum 2009), something that the recent neoliberalization of the Indian economy further has contributed to (Evans and Giroux 2015; Varman et al. 2012). Raghuram (1993) adds that women service providers have little control over the money they earn because the men in their households typically control it. Therefore, women service providers face double marginalization in both their places of work and in their homes. Dickey (2000a, p. 477) further points to a common charge in which women service providers are accused of trying "to gain control over men and usurping the wife's role as the creator of family and the lover of her husband." As a result, these women are seen to be threats to their own household power structures.

Class is another significant constituent of the hierarchy that defines clients and kajer lok. Dickey (2000b) observes that the presence of domestic service providers is a necessary marker of class in India. Class is determined by both economic and symbolic factors (Dickey 2000b). Ray and Qayum (2009) observe that the hiring of servants is done to acquire a middle-class status and that these servants are treated as subordinates. Moreover, service providers introduce the dangerous outside into an orderly and protected inside and this leads to concerns about dirt, disease, and immorality (Dickey 2000a; Douglas 1966; Jaffe and Dürr 2010). Hence, service providers represent a dangerous mix of outside and inside. To protect their homes, clients discipline physical movements and sexual activities of service providers, and maintain distance.

Further, caste-based status hierarchies and lingering ideas of untouchability produce clients and kajer lok (Froystad 2005; Raghuram 2001; Tellis-Nayak 1983). Accordingly, upper castes, to which most of the clients we studied belong, consider lower castes as impure and polluted. Douglas (1966, p. 140) further notes that, "the pollution became a doubly wicked object of reprobation, first because he [the polluter] crossed the line and second because he endangered others." Because upper castes are considered pure, it is necessary to maintain distance, and any physical contact by lower castes is considered dangerously polluting and subversive. Teltumbde (2010, p. 10) laments that "caste has showed an amazing resilience. It has survived feudalism, capitalist industrialization, a republican Constitution, and today, despite all denial, is well alive under neoliberal globalization." It should be further understood that caste is not merely a system of vertical stratification as Dumont (1970) theorized it, but also involves horizontal differentiation (Gupta 1991). In its horizontal form, there are many castes that are at the same hierarchical level but are considered wholly distinct from each other. Lower caste service providers deal with household waste or pollutants that further reify their subordinate positions. Moreover, violence against lowers castes by upper castes is legitimized by Hindu texts such as the Manusmriti. For example, Manusmriti (undated) 
recommends, "If the shudra intentionally listens for committing to memory the veda (ancient Hindu religious text), then his ears should be filled with (molten) lead and lac; if he utters the veda, then his tongue should be cut off; if he has mastered the veda his body should be cut to pieces." Violence against the low caste continues in contemporary India and in a recent piece, Namala (2016) notes, "The growing violence against Dalits (low castes) follow a clear pattern. These incidents are directed towards reminding Dalits about their status in the caste-based social structure, and ensuring that they remain there. These atrocities are committed to ensure that Dalits live a life of indignity, humiliation and exclusion from the mainstream society."

In summary, existing writings suggest that historically constructed social distinctions and status hierarchies of caste, class, and gender produce consumers, shape domestic services, and lead to exploitation of female service providers in multiple ways. However, previous studies have neglected the role of normative violence in consumption that exacerbates conditions of exploitation of domestic service providers, whose lives are made ungrievable.

\section{Normative Violence and Ungrievable Lives}

Butler (2004a) interprets violence as a form of exploitation of the fundamental human tie of interdependence. Accordingly, violence is damaging the other, putting it at risk, and threatening to expunge it as a subject. Violence against the other often takes place as and in a state of derealization, which is a condition of desubjectification that positions the derealized person as "neither alive nor dead" (Butler 2004a, p. 32). Adopting a critical perspective, Butler (2004a) points to normative violence or the violence inflicted by normalized frameworks that organize social worlds. Specifically Butler (2004b, 2005) suggests that norms produce institutionalized scripts which must be understood as forms of actions because they are not static conditions that are imposed on subjects. Norms are actively lived and interpreted to constitute the subject. Although Butler (2009, p. 4) cautions against a deterministic reading inasmuch as "different normative schemes are interrupted by one another," she suggests that norms encode the operation of power and violence by controlling who counts as a human. Norms create a grid of intelligibility and those who become unintelligible are susceptible to violence. Thus, norms are violent in categorizing people and in creating conditions for further violence against those who are derealized.

Norms are not the same as rules or laws for how people should act and think. Drawing upon Foucault, Butler (2004b, p. 41, emphasis in original) sharply points out that "a norm operates within social practices as the implicit standard of normalization." Therefore, norms may not be explicit and are often difficult to read and discernible only in the effects they produce. Giving the example of gender, Butler points out that understanding of gender as a norm cannot be conflated with normative views of femininity and masculinity or binaries of man/woman or male/female. In fact, reduction of the norm of gender to these binaries reveals how norms produce effects of naturalization because they foreclose all other possible readings of gender beyond male and female. Similarly, it becomes necessary to understand how norms produce normalization of violence and remove the possibilities of moral outcry against exploitation and coercion. Moreover, Butler does not see norms as exterior to its field of application or as a producer of a field of application. Instead, the norm produces itself in the production of that field (Butler 2004b).

Butler (2004b) further emphasizes the ideas of livability and grievability. The two are connected because only those whose lives are livable will have deaths that create grief. The ungrievable subjects are those that have been derealized, which makes people less human or dehumanized implying that violence may be inflicted against them without ethical dilemmas. Butler (2004b, p. 33) insightfully notes that, "if violence is done against those who are unreal, then from the perspective of violence, it fails to injure or negate those lives since those lives are already negated." Butler (2009, p. xii) draws connections between precarity and ethics, and suggests that it is necessary to pay attention to, "who' can become produced as a recognizable subject, a subject who is living, whose life is worth sheltering and whose life, when lost, would be worthy of mourning. Precarious life characterizes such lives who do not qualify as recognizable, readable, or grievable." Accordingly, the capacity to recognize a life is dependent on that life being produced according to norms that qualify it as a life. People draw upon norms to negotiate everyday existence, derive agency, and constitute personhood. Butler (2004b) further asserts that our very lives depend on there being norms of recognition that produce and sustain our viability as humans. Norms mark lives as real and unreal, creating moral distance between people (Huber and Munro 2014). In this way, Butler (2009) surfaces the politics of ontology and epistemology through which recognition is granted to different entities in a process by which domination and subjugation are achieved.

Only by engaging in a critique of the norms that constitute the subject, can a person or institution take responsibility for its actions. Here, Butler (2009) differentiates between a more precise idea of recognizing and a less clearly understood notion of apprehending. She argues that a life can be apprehended or roughly understood without there being precise norms of recognition. In this imprecise understanding or apprehending lie the seeds of a potential critique of the norms of recognition. As Butler (2009, p. 15) observes, "we can apprehend, for instance, that something is not recognized by recognition. Indeed, that apprehension can become 
the basis for a critique of norms of recognition." Critique also implicates the self since the very norms that constitute the subject are the object of critique. While Butler perceives responsibility as central to ethics, she argues that responsibility needs to be rethought due to the fact that the subject is constituted by social norms. Therefore, reflexivity becomes central to responsibility. However, reflexivity is not only socially mediated, but socially constituted (Butler 2004b). Responsibility, Butler (2005, p. 83) argues "cannot be tied to the conceit of a self fully transparent to itself. Furthermore, to take responsibility for oneself is to avow the limits of self-understanding, and to establish these limits not only as a condition for the subject but as the predicament of the human community." Here, responsibility means that a shared condition of existence and grief must be apprehended and recognized. Grief is a pre-requisite for a livable life. Butler (2004b, 2009) suggests that grievability as a shared condition helps people to recognize and take responsibility for each other as humans who are equally vulnerable. Butler (2009, p. 29) insightfully adds, "the recognition of shared precariousness introduces strong normative commitments of equality and invites a more robust universalizing of rights." For Butler ethics of grievability is an intervention into power relations that regulate the recognizability of losses and violence (Karhu 2017). According to Butler (2004b), grief is an important ethical and political resource because it helps develop identification with suffering and sufferers.

In summary, comprehension of normalization of violence in consumer ethics requires a deeper understanding of the role of social distinctions in exploitation and coercion. Moreover, how lives are made ungrievable in a manner such that violence against them unfolds in state of ellipsis has to be better understood to comprehend lack of moral outrage among higher status clients. It is to these aspects of social distinctions, status hierarchies, normative violence, grievability, domestic service, and consumption that we turn to in the rest of the paper.

\section{Methods}

We conducted this study in Kolkata, one of the largest cities in India, located in the Eastern state of West Bengal. This city is a suitable site for our research for several reasons. First, Kolkata is home to a vast subaltern population that lives in proximity to a substantial community of middleclass knowledge workers. Second, Kolkata is an important urban center that is traditionally a center of migration for the rural subaltern population. But the economic opportunities are primarily low-end jobs and many migrants end up providing cheap unskilled service to households in the city.

Our purpose in this study is to examine the kajer lok's subjective experience as a service provider. We also wanted to understand how clients interpreted their roles as service consumers. We conducted long interviews with 19 kajer lok participants and 10 clients (McCracken 1988). We recruited these female participants using purposive sampling (Tables 1, 2 contain profiles of our participants). In
Table 1 List of Kajer Lok participants

\begin{tabular}{lllll}
\hline Name & $\begin{array}{l}\text { Age (approxi- } \\
\text { mate) }\end{array}$ & Education & Experience (years) & Experiences of violence \\
\hline Alpana & 37 & Some school & 30 & Caste-based segregation \\
Anjana & 40 & Some school & 25 & Caste-based segregation \\
Ashima & 48 & No school & 30 & Physical and sexual violence \\
Roli & 25 & No school & 12 & Sexual violence \\
Bharati & 52 & Some school & 30 & Caste-based segregation \\
Kalpana & 36 & Some school & 25 & Physical violence \\
Lakshmi & 36 & No school & 26 & Caste-based segregation \\
Mita & 46 & Some school & 30 & Physical violence \\
Vinita & 44 & Some school & 25 & Caste-based segregation \\
Ahana & 24 & Some school & 8 & Sexual violence \\
Rita & 25 & Some school & 12 & Sexual violence \\
Sancharia & 16 & Some school & Less than 1 year & Caste-based segregation \\
Malati & 35 & Some school & 6 & Caste-based segregation \\
Sumitra & 45 & Some school & 13 & Physical violence \\
Sushmita & 32 & No school & 15 & Physical violence \\
Tulsi & 22 & No school & 10 & Physical violence \\
Mangala & 46 & School pass & 10 & Caste-based segregation \\
Chameli & 42 & Some school & 20 & Caste-based segregation \\
Leela & 40 & Some school & 20 & Caste-based segregation \\
\hline & & & & \\
\hline
\end{tabular}


Table 2 List of client participants

\begin{tabular}{llll}
\hline Name & Age (approximate) & Education & Profession \\
\hline Soma & 35 & Under graduate & Homemaker \\
Susmita & 38 & Under graduate & Service \\
Brinda & 42 & Under Graduate & Homemaker \\
Anita & 35 & Secondary school & Homemaker \\
Chabi & 56 & Under graduate & Homemaker \\
Koyel & 57 & Under Graduate & Homemaker \\
Arati & 63 & Under graduate incomplete & Homemaker \\
Suparna & 33 & Under graduate & Homemaker \\
Tapasi & 50 & Under graduate & Homemaker \\
Jugal Kishori & 72 & Some school & Homemaker-unmarried \\
\hline
\end{tabular}

this study, we have specifically highlighted experiences of violence faced by kajer lok. In Table 1, we provide a brief description of violence faced by kajer lok.

During the study two of the authors were located in Kolkata, and one speaks the native language, Bengali. The interviews were done with the help of female research assistants, who were also native Bengali speakers. Female research assistants were necessary to overcome the gender divide that marks the cultural setting in which women hesitate to talk to men who are perceived to be strangers. Engaging female research assistants was also a necessary ethical step in conducting research by ensuring that women participants did not feel threatened in sharing their experiences. Research assistants were given a broad discussion guide to follow. However, the list of issues discussed in these interviews evolved as we came across new sets of topics during the fieldwork. Research Assistants started the interviews with some of the kajer lok they already knew. These interviews allowed us to establish a preliminary framework of analysis that helped us to purposefully recruit more participants. Interviews were carried out with participants after taking their consent at convenient sites, which often turned out to be their homes. This was another important ethical step to ensure that kajer lok could describe their experiences away from the gaze of their clients. A typical interview with kajer lok started with a conversation to elicit background information on the participant's life, such as place of birth, marital and family status, education level, current job, and income. Interviews then proceeded to questions about the woman's current life situation, including service and family experiences. Clients were asked to describe their experiences with kajer lok and the services they provided to them. Interviews were recorded and lasted 60-90 min. They were then transcribed in Bengali and translated into English. To safeguard the identities of our participants, we have used pseudonyms throughout the paper. This ethical standard is especially essential with vulnerable participants such as kajer lok.

Our interpretation of the interview texts was conducted through a hermeneutical process that involved continuous movement between transcripts and the emerging understanding of the entire data set (Gadamer 2004). We started the analysis by closely reading each interview transcript to identify different themes of violence through open coding. We further identified different social norms and market practices that structured domestic service and social distinctions. For example, we identified different aspects of value extraction, physical violence, and class in our interviews. We pooled these open codes together to create a set of linkages through axial codes that we read in the context of different life experiences of our participates. Finally, moving through text and context helped us to establish relevant linkages with theorization of domestic service and the status hierarchies of class, caste, patriarchy, and market. In the selective codes that we finally identified, we integrated the relationships among status hierarchies, consumption, normative violence, grievability, and exploitation. The theoretical understanding that we present reflects a stage of the analysis in which it is possible to establish linkages between meanings expressed by participants and a broader set of economic, political and theoretical issues. In the following section, we present our findings.

\section{Findings}

In this section, we explain how different social distinctions and status hierarchies of class, gender, and caste constitute consumers/consumption, and create ungrievability (Butler 2004b, 2009). We show how kajer lok are physically abused, sexually violated, and cast aside as unfit for upper class/caste consumption. Consuming/serving subjects bring together diverse aspects of the social world and create consumption/service in which normative violence unfolds. Such consumption normalizes violent exploitation and further exacerbates vulnerabilities of kajer lok, who are reduced to ungrievable lives. However, violent exploitation is challenged and resisted by some kajer lok and clients in different ways. In the final section of our findings, we analyze 
resistance to violent exploitation by attending to how these attempts to apprehend the lives of kajer lok may make them more grievable.

\section{Ungrievability Through Class-Based Consumption}

We found that some middle-class clients drawing upon their class positions deployed physical abuse against kajer lok as part of their consumption that reinforces social distinctions. Unlike status struggles and contested forms of symbolic capital, as Üstüner and Thompson (2012) have uncovered, we witness a status hierarchy becoming an apparatus of physical violence and exploitation. Physical violence by clients is tethered to the idea of improving middle-class consumption by extracting service and value from lower class service providers. Ashima's experiences as a domestic service provider were instructive,

I made mistakes at times in my work [...] Then they shouted at me viciously. [...] One day they sent me to market to buy sweets. In that shop, that sweet was not there. So, I brought that sweet from a different shop. The price was higher there. I could not give them back the leftover change. That woman (client) pulled me by my hair and beat me brutally. No one in the house stopped her. I cried a lot that night. I thought that I would never do this work. I thought even if I die of hunger I will not do this work.

The violence inflicted by the client is encoded in the classbased norms of consumption and in their contradictions. Middle-class clients are simultaneously expected to spend money to establish their class-based positions and to be thrifty and save for future consumption (Baviskar and Ray 2015). As Butler (2009) observes, conflicting norms can create displays of dominance as is the case with this client. Ashima's employer's deployment of violence is both a sign of her class-based domination over Ashima and her desire to enhance her own consumption and status. In this instance, improved consumption of the client and social distinctions are tied to saving money by not paying extra for sweets, a service that Ashima failed to provide. Ashima is approximately 50 years old and has no formal education. Her description of physical violence and abuse involved her experience when she was a 17-year-old girl. At this point in time she was staying in the client's home and working $16 \mathrm{~h}$ a day for a salary of INR 60 per month (USD 1).

Young kajer lok are particularly susceptible to such violent class-based exploitative consumption because they find it difficult to leave their clients. In this case, Ashima could not leave her client because she came from a very poor family and as a 17-year-old woman she was too young to leave without another source of income. This is a structural form of unfreedom that is furthered by market forces of supply and demand (Arnold and Bowie 2003; Bales et al. 2009; Preiss 2014). Such a market state robs Ashima of the freedom to refuse work and to reclaim her personhood in the face of consumer violence. In a labor surplus job market that neoliberalism has furthered (Evans and Giroux 2015; Varman et al. 2012), Ashima knew that it was difficult to find another job to survive. The client believed that the price she was paying for Ashima's services allowed her to command Ashima the way she wanted and to dole out vicious punishments for perceived non-compliance with expectations. This outcome, which Butler (2004b) describes as derealization because Ashima was denied respect and freedom to be a human being, was created by the class differential between the service provider and client, desire for enhanced consumption, and the market conditions.

Violent exploitation of Ashima unfolded in a state of silence and her pain was of little consequence to the remorseless client. Within the class-based consumption order we studied, it was normal to use violence in response to Ashima's failure to provide adequate service from the client's point of view. Thus, Ashima could be beaten and exploited without inducing grief and moral compunctions among clients. Butler (2004b) labels this as a state of ungrievable life. Ashima further informed us,

If I broke anything, they wouldn't spare me. One day dishes fell from my hand. I was beaten badly that day. Again, sometime later, they asked me to bring mustard seeds and to make a paste of that. After I had pressed the mustard seeds, it turned bitter. And they cooked fish curry with that. That day that lady punched me on my chest. She accused, "You bought inferior quality and cheated the rest of the money. Give us back the money quickly." She punched me viciously. I was not in a condition to speak. She told me, "A lot of expensive fish is wasted, who would pay the money, tor baba debe (your father)?" That lady picked my suitcase and threw it out on the road and asked me to go out from their house at that very moment. I told her, "Inform my father, he will come to get me." They did not hear me. They pushed me out from their house. They did not even pay me for five months of work. It was an afternoon that time. I did not know the way back home.

Ashima was physically beaten up for small failures to meet the consumption expectations of her client and was thrown out of the house by her client for not getting a recipe right. Her family lived in a village near Kolkata, and when the client threw her out, she did not even know how to return home. She got some help from her fellow service providers, and they helped her to return to her family. However, as an additional layer of exploitation, her client did not pay her for nearly five months of work, and she could not do anything about it. As Raghuram (2005) has argued, these service 
providers work with no written contracts and payments are made in cash with no records of such transactions.

Ashima's response to physical violence also reveals the limitations of the client's deployment of ungreivability, frames of recognition, and normative control (Butler 2009). Ashima did not accept the use of violence as legitimate and refused to see herself as an ungrievable life. Instead, it was the fear of further violence that kept her quiet. When we asked Ashima about her response to physical abuse, she told us, "No, I could not say a word. I was petrified. Sometimes I muttered to myself. I was too afraid to say anything in front of them." Moreover, to challenge a middle-class client, a kajer lok needs access to police and courts, all of which requires money that they do not possess. Even after nearly 23 years of working Ashima earns a mere INR 2500 per month (about 40 USD). She lives in a single room temporary house that is damp and wet during the rainy season and cold in the winters. As a result, her son died of pneumonia at age eight and her husband died of untreated asthma a few years later. However, these tragedies did not prompt her clients to apprehend Ashima's grief nor deter them from continuing to exploit her because in their frames these ungrievable lives counted for little (Butler 2004b; Joy et al. 2015).

Older women have a greater ability to resist physical violence than younger woman. However, the threat of violence in the form of verbal abuse is regularly repeated between clients and older kajer lok. Tapasi, a client, explained to us,

I do get angry with her (kajer lok) sometimes. That's because she is very moody. On some days, she works very carefully but sometimes she is so negligent that I cannot help but scold her. Sometimes she doesn't care to wash the garments properly - she will not rinse the detergent from the wet cloths and let it dry. If I am not supervising, she will leave the mopping work half done. It is not possible to be vigilant all the time. I hardly go to the third floor to supervise her work. However, whenever I do so she gets furious [Tokhon tere tere ashe] and starts quarreling with me in a harsh tone. She even threatens me that she will leave the job after Durga Puja so I better start looking for another help. I also retort back that she is free to make her choice; there is no dearth of domestic helps. This has happened quite a number of times. But she didn't leave. She came back the very next day and stated working normally.

Beyond any utilitarian justification in an effort to extract better service, verbal abuse is seen to be necessary by clients to establish their higher-class positions, attain desired levels of consumption, and for the exploitative value extraction process to work effectively. In a way, these encounters between kajer lok and their clients are often laced with anger and dissatisfaction as the two sides find themselves located in a discourse of class that is not of their making (Butler 2014). Waldrop (2004) attributes the middle-class anxiety regarding domestic service workers as arising from crumbling of old rigid status boundaries as also detected by Vikas et al. (2015). In order to maintain their often newly achieved middle-class status, clients need to emphasize imagined distinctions in dress, spaces, objects, speech, and other aspects encoding high/ low, clean/dirty, and pure/impure distinctions (Baviskar and Ray 2015; Dickey 2000a; Fernandes 2006). These are old and well-entrenched categories in India, but contemporary consumption-based status anxiety revivifies and amplifies them (Mattila 2011). Middle-class clients believe that the only way to keep their rather tenuous position is by extracting value from lower classes (Baviskar and Ray 2015; Fernandes 2006). Violence by clients also betrays their fear of becoming vulnerable because of the actions of kajer lok. Clients commonly attribute violence to being prompted by negligence on the part of service providers. They believe it becomes necessary to make service providers understand their consumption requirements. As Butler (2014) reminds us, this is a case of clients claiming vulnerability to shore up their privileges.

In summary, consumption that is embedded in violent exploitation reinforces social distinctions and normatively reproduces the moral distance between the high and low classes (Huber and Munro 2014). Further, and going beyond Bourdieusian analyses of status hierarchies and their occupation with symbolic power, we identify how domestic service is an arena of anger and dissatisfaction for both clients and service providers because both feel vulnerable as they find themselves located in discourses that offer them limited choices. In class-based consumption practices and in structural market conditions of disparity, under-class service providers become ungrievable and violent value extraction by clients normalized.

\section{Ungrievability Through Patriarchal Commodification}

A kajer lok's limited ability to become grievable and to resist violence is also an outcome of the structures of patriarchy (Dickey 2000a; Kumari 1989; Raghuram 1993, 2001). Kajer lok face two overlapping circuits of violence that are rooted in patriarchal consumption. First, service providers face violence in their homes because of men wanting a bigger share of family earnings for their personal consumption. Second, male clients commoditize kajer lok and treat them as objects for their sexual gratification.

Many of kajer lok report that they have experienced high levels of repeated domestic violence and abuse from men in their families. Tulsi informed us, 
From my early childhood days, I saw my mother being beaten up by my father. My father worked in a factory, and he was an alcoholic. One day he poured kerosene and set my mother on fire. I do not correctly remember that incident. I was five then. Everybody says that when my mother was burning she hugged me tightly, and my arm and a leg were also burned. Our neighbors admitted us to a hospital, but my father absconded, and he never came back to us. When we recovered, my mother went back to Andhra Pradesh with us, where we had a place to live with our maternal uncle. But we could not stay there for too long, there were lots of problem in my uncle's house. We had to come back here [to Kolkata] and my mother started working as a kajer lok. Often my elder sister and I went with my mother to help her. As my mother's face was burnt, she could not get much work. We could hardly buy our rice and sambar (lentil soup) in a day. After that, my mother engaged my elder sister as a kajer lok in 2-3 houses. My elder brother got work in a shop and after that, he worked as an apprentice to a mason. I also went for work with my sister. I helped her in cleaning dishes. I was then 7-8 years old. Since then I am working as a kajer lok.

Tulsi came to Kolkata from Andhra Pradesh in South India along with her mother in search of a livelihood. She is now a 22-year-old, was briefly married before her husband left her, and earns around INR 750 (USD 12.5) per month from her domestic work. Tulsi's story of domestic violence finds strong resonance across our participants. The patriarchal order is made worse by alcohol consumption of men that ensures that the subaltern women suffer violence both in their domestic and commercial encounters (Joy et al. 2015). As in the case of Tulsi, it is common to see the occupation of domestic service provider being inherited from one generation of women to another, while men in their houses take away for their personal consumption the little money they earn. Such violence against women is encoded in male consumption and normalized. Patriarchy ensures that the violence against women goes unnoticed because it is a common practice. As a result of these family circumstances and patriarchal violence, many of these service providers start working from a very young age which makes them particularly vulnerable to different forms of violence.

Our findings also suggest that the patriarchal order permeates market interactions toward kajer lok. Male clients reiterate patriarchy, objectify women, and reduce them to commodities who are expected to not only provide services for which they are contracted but also provide sexual favors. In line with prior research (Gettman and Gelfand 2007; Varman et al. 2018), we found instances of sexual violence by male clients against kajer lok. Sexual violence is critical to the establishment of patriarchal structure because it reinforces the domination of male clients (Butler 2004a; Menon 2012). Unlike the experiences of status hierarchy and domination being confined to objects of consumption, as reported by Üstüner and Holt (2007), we witness something fundamentally different. We find that status hierarchy allows objectification of kajer lok and their violent exploitation. Indeed, we witness a conjoining of the market-based logic of consumption with patriarchy. Ashima, described the following experience as an 18-year-old in which sexual exploitation was central,

When I first was engaged as a day-night domestic help at that very house, there was a brother of that Boudi (client). He went there every Sunday. He tried to touch me several times. At that time, I was young and was not married. I was afraid of him; I used to get overwhelmed by a strange sense of fear and terror. Whenever I saw that man, I used to hide from him. He called me to give me INR five [about 7 cents] and tried to touch my breasts. Once I also told him, "What are you doing? I am much younger than you." Then he told me, "You promise me not to disclose this." He gave me more money. I did not want to take the money. But there was a strange fear, I was not able to say this to anyone of them. I could not speak anything or tell him that I won't take the money due to a certain sense of fear. That man again did that to me. Yes, he touched my breasts many times. I was not able to accuse him. Whenever I saw him, I got afraid.

Ashima almost whispered her account of this experience to us with a strange sense of guilt. Her sense of helplessness and trauma were evident in her behavior even decades after this experience. Despite experiencing sexual assault from a member of her client's family, she could not afford to leave her job and had to continue to serve for years with this lingering fear. Ashima knew that her clients believed that they owned her as an object of consumption because she was being paid a price for her services. The logics of markets, consumption, and patriarchy also ensured that she could be sexually violated, and some money (INR five in this case) could be doled out to her as a price for that consumer service. Another service provider, Roli, faced similar sexual exploitation,

In Dadu's (client's) house, there comes a Dadu's friend who is younger than Dadu. Once Dadu asked me to give a glass of water to his friend. I went to the kitchen to take water, and then I saw that the friend had also walked to the kitchen with me. I took the glass and tried to hand it over to him, he took the glass and tried to touch my breast. I said nothing but glared at him. No, I never informed Dadu about this incident. After 
all, he is a male, what can I say to him? After that, whenever that person comes to Dadu's house, I never go near him.

Roli's experience shows that commoditization of her body was not just limited to her clients. A visitor at the client's home could also show the audacity and knew rather well that an ungrievable entity would not be in a position to lodge a complaint. In most cases, kajer lok's silence is not a sign of acceptance of the dominant norms or symbolic power of their clients (Bourdieu 1990; Üstüner and Thompson 2012) but rather of their inability to challenge the frames of recognition that their clients deploy. As a result, Roli dismissed the idea of complaining to her client as an exercise in futility. Because of structural conditions of production of consuming/serving subjects shaped by markets and patriarchy, such forms of exploitation of kajer lok continue to unfold in a state of normalization that is marked by silence and lack of moral compunctions. There is possibly a realization by Roli and Ashima that they will be 'worse-off' in the absence of such clients (Powell and Zwolinski 2012). However, any moral permissibility of such a state will not only need to overlook structural conditions of exploitation (Preiss 2014) but also specific norms that allow violent exploitation against ungrievable lives to unfold in a normalized state of ellipsis.

In summary, we find two mutually reinforcing features of normalization of violent exploitation that stem from social distinctions and status hierarchies. On the one hand, kajer lok are made ungrievable and reduced to commodities that can be sexually abused by their higher status clients without any fear of legal or social sanctions. These clients believe that the price paid for services allows them to violate lower status kajer lok and consume their services in various ways. On the other hand, kajer lok as victims of sexual abuse do not accept such normative frames deployed by their clients and negate their symbolic power but stay silent because of the structural conditions of commodification created by markets and patriarchy.

\section{Ungrievability Through Caste-Based Consumption}

A common feature of violent exploitation of kajer lok is hierarchization and segregation of the consumption rights of kajer lok. Consumption by kajer lok in such a segregated context becomes a site for the application of caste-based power and abuse. Consumption helps to reinforce and materialize caste through which kajer lok are made ungrievable. Alpana, a kajer lok informed us,

They (clients) gave me tea in a separate cup and also separate my plates. Yes, I felt bad about it. Then I thought as I work as a domestic help they could do this to me. Or was it because I am poor? I really felt bad.
Alpana is a married 37-year-old with a son and has a family income of around INR 7500 (125 USD) annually. She lives in her own house and has a steel cupboard, television, fridge, and a cell phone as her major possessions. Similar to the observations made by Vikas et al. (2015), these consumption achievements narrow the distinctions between her and her clients, likely provoking greater status anxiety on her part. Echoing Butler's idea of derealization, she reports that her clients treat her as an unequal consumer and do not even allow her to use their dishes. The question of caste further adds to these segregations. Koyal, a client, informed us that her kajer lok uses separate dishes,

She (kajer lok) has a separate cup for tea. Frankly speaking, in my family, each member has a separate cup for tea. We do not have tea from other person's cup. That is why her cup was also a separate one from ours.

Interviewer: Suppose there is a situation that there are many guests in your house, would you mind having tea from your daughter's cup?

Yes, why not? If situation so demands I will certainly not mind having tea from her cup. She is not an untouchable.

Interviewer: In a similar situation would you mind having tea from Guddi's (kajer lok) cup?

Oh my God, no! I will never have tea from her cup. Is she the same as my daughter? She is so dirty. When we used to offer her tea, she didn't care to wash her hands after sweeping or mopping the floor. She used to take biscuits in the unwashed hands...How can we have tea from the cup of such an unhygienic girl Oh, no, never! [Her face reflected abhorrence]

While the Bourdieusian analysis by Vikas et al. (2015) helps to understand some aspects of the functioning of the status hierarchy in our setting, we find Butler's reading of attempts to appropriate vulnerability particularly helpful for a more complete understanding. Butler (2014) insightfully helps us to see that clients as dominant actors try to appropriate vulnerability by projecting themselves as vulnerable. In this case, we witness vulnerability of an upper caste client to pollution because of the presence of impure lower caste kajer lok. As Douglas (1966, p. 114) observes, "a polluting person is always in the wrong. He has developed some wrong condition or simply crossed some line which should not have been crossed and this displacement unleashes danger for someone." Koyal refers to several aspects of caste-based segregation to project herself as vulnerable. In the Hindu caste system, upper castes have traditionally denied subordinate castes access to their food, water, and places in which food is prepared (Béteille 1996). Some of these norms have changed in urban settings, in which kajer lok are needed by clients to cook their food or clean their dishes and houses. 
However, it is common to see different dishes set aside for kajer lok to have tea and food or ask them not to put their mouths on dishes. These consumption norms are based on the prevalent caste-based system of purity and pollution in which the lower castes, to which most of the kajer lok belong, should not allow their saliva to touch any of the dishes used by upper castes (Vikas et al. 2015). It is common to see kajer lok pouring water in their mouths from a distance when they use glasses used by their clients. This is to ensure their saliva does not contact and pollute clients' dishes (Jaffe and Dürr 2010). It is a form of untouchability in consumption that is commonly experienced by kajer lok. Because of these consumption norms, clients do not feel any moral compunctions in treating kajer lok in a manner that is discriminatory, exploitative, and violent. Again, we see how consumptionbased status anxiety conjoins with caste boundaries and indices of dirt and pollution (Dickey 2000a; Harju 2017; Mattila 2011). Scrambling for distinction in an increasingly socially fluid society means reinforcing boundaries through a discourse of pollution and contagion. Choon-Piew (2007) finds similar concerns with symbolic pollution in socially volatile China. There too domestic service workers are seen as a necessary evil and as dirty, uncouth, and polluted.

The clients' positions of caste-based dominance give them the power to treat kajer lok as inferiors who should be segregated and kept at a distance (Butler 2009). Therefore, Tulsi told us,

Everybody looks down upon us. I worked in a household for one year. They did not allow me inside. They asked me to wash utensils in their terrace. If it was raining, then I had had to clean the utensils in the rain. They did not allow me to sweep rooms. One day I was angry, and I told them, "Don't you think we are humans? Is it possible to work in such a heavy rain?"

It is common to see subaltern service providers not getting complete access to homes they work in. When they visit these homes, they are often made to stand at the door or asked to confine their presence to certain parts of houses. They cannot use the elevators in the buildings where their employers live. It is also common to see kajer lok leaving their footwear outside their client homes before entering. This is done to ensure the dirt they carry from their subaltern settings does not pollute the sanctity of clients' homes. On the other hand, people of the same or higher class are commonly welcomed inside these homes. They are allowed to wear their footwear inside these houses, whereas they are removed at designated religious places. Hence, through consumption and violence of segregation the lives of kajer lok are made ungrievable (Butler 2004a).

When we questioned the clients about these castebased consumption norms, Sumitra, told us, "she (kajer lok) is not allowed to sit on the bed. Will you allow that in your house? They work in different houses, their clothes are often dirty. If they sit on our bed wearing those dirty clothes is it possible for us to sleep on that bed again?" These clients make domestic service providers ungrievable by claiming that they are unclean, diseased, and dirty. On the one hand, kajer lok are treated as untouchables, inflicted with the violence of segregation, and on the other hand they are made to work long hours under conditions of violent exploitation. It is common for clients to consider such treatment of kajer lok as normal and moral. In these narratives, there are several references to kajer lok's existence as incomplete consumers who do not wear proper clothes or are considered to be unhygienic because of their inability to consume products of personal hygiene. As Butler (2014, p. 5) informs us, "We do not only act through the speech act; speech acts also act upon us." In many cases we may not see physical violence but name calling and verbal abuse by clients are common, and they reduce kajer lok to lesser entities. Hence, in the light of caste, markets, and consumption it becomes normal for consumers to treat kajer lok as ungrievable lives, who can be violently exploited (Butler 2004b, 2009).

While some kajer lok recognize this form of violence in consumption and do not accept these norms, many other victims see these hierarchies, segregations, and distinctions and the upper-class behaviors as normal. Sumitra, a kajer lok explained,

I never feel bad about not being allowed to sit on a sofa. I suppose this place (floor) is for me. In my initial days, they told me that I was dirty. Just like when they asked me to do something, they always said, "you can touch that after washing your hand." They also forbade me to sit on the chair. I always sat on the floor. And till now I maintain this habit. No one forbids me now, but I cannot sit on a chair till now. I never dare to sit on their bed. I feel guilty if I sit on their bed.

Sumitra as an exploitee has accepted her inferior status and does not feel comfortable in crossing the class-based distance. This form of exploitation is internalized and does not lend itself to calculations of worseness or free choice (cf. Powell and Zwolinski 2012). Sumitra's narrative supports Üstüner and Thompson's (2012) suggestion that the symbolic domination and habitus reconfiguration of some low cultural capital service workers is premised upon the middle and upper classes norms (Bourdieu 1990). Thus, clients do not often need to actively derealize because kajer lok themselves contribute to the creation of their less worthy lives through the internalization of dominant consumption and caste-based norms (Butler 2004b). Sanchariya, a kajer lok, informed us about a similar situation of normalized violent exploitation through internalization of dominant norms, 
Our client said, "You go to work with the same skirt, don't clean yourself or maintain proper personal hygiene and without changing you enter my room and sit on my bed. I don't like this." Yes, I felt bad that day. But still I go there, and now I do not sit on the bed. I sit on the floor. No, I sit on the floor by myself. I am afraid to sit on the bed. What if they shout at me? No, I have no courage to sit on the master's bed. I think I am dirty. Because I clean their dirty utensils, after that if I sit in their bed are they going to encourage that? So I never have that courage.

Sanchariya is a 16-year-old girl with education up to class six and helps her mother who works as a kajer lok. Her family comprised of mother, father, and an elder sister earns only INR 1500 (25 USD) a month and stays in a thatchedroof shanty. Sanchariya is scared of verbal abuse from her client if she is caught sitting on their bed. However, she also believes that as a consumer she is dirty and does not deserve an equal status. Through the exposure to caste-based norms of consumption, she is derealized (Butler 2004a, 2009). And this normative violence leads to the creation of ungrievable life as kajer lok become lesser beings for whom nobody needs to take responsibility.

In summary, we find that status hierarchies of caste, class, and gender shape consuming/serving subjects and consumption that contribute to normative violence (Butler 2004b). In particular, we point to how differential positions of consumers and consumption reify norms and make them into social facts that make the life of kajer lok ungrievable. While Bourdieusian analyses of symbolic power in the writings of Vikas et al (2015), Üstüner and Thompson (2012), and Üstüner and Holt $(2007,2010)$ help to see some of the experiences described above, we point to contests of vulnerability and creation of ungreivability as important features of social distinctions in our setting that contribute to normalization of violent exploitation. However, normalization of violent exploitation does not mean that kajer lok accept their status as ungrievable lives or that all clients refuse to apprehend their lives as subjects. We elaborate on these facets of resistance to ungreivability in the following section.

\section{Resistance to Ungrievability}

Although normative violence encoded in social distinctions and status hierarchies leads to widespread relations of exploitation, there are some kajer lok who refuse to accept these conditions of vulnerability and offer resistance. In some cases, we came across clients who make attempts to apprehend the lives of kajer lok and treat them with kindness (Butler 2009). As Butler (2014, p. 15) notes, "resistance to vulnerability wishes that it were never the case that discourse and power were imposed upon us in ways that we never chose." In some cases, this resistance makes the lives of kajer lok more grievable, which according to Butler (2004b, 2005) has ethical and political consequences because it may induce privileged subjects to take responsibility for sufferers.

We find that markets act as a double-edged sword for kajer lok to resist violence and in making their lives grievable. The resistance to vulnerability that we witness by kajer lok is premised upon attempts to wriggle out of dominant discourses and power of clients by creating some avenues of choice (Butler 2014). A few kajer lok report that they have managed to change their work, and by doing that they have some respite from exploitation. Some of these shifts are within the ambit of domestic work. For example, Vinita, who previously worked as a kajer lok and did cleaning now works as a cook, and found more respect in her new job. She told us,

Now I get more respect by working as a cook than previously when I was working as a housemaid. I can open the fridge to take out food items; I can cook the way I want. Previously when I used to clean utensils people never treated me with respect. They never asked me to sit. I used to do my job and leave. They used to serve me tea in a separate cup as if they used to abhor me. Now they don't do that. I can eat and drink from the same dish and cup that they use. I am even allowed to sit on their beds. Previously I dared not to do that.

Vinita's description suggests that marginal positive shifts in levels of exploitation that contributes to making life more worthy are possible. Cooking as a category is more socially exalted compared to cleaning that requires everyday handling of filth and dirt. Cooks are usually treated with more respect as compared to kajer lok who do the cleaning work. Such a shift offers some relief and a sense of freedom that is greatly valued by kajer lok. However, these shifts are within the dominant normative framework and such moves to lesser vulnerability do not necessarily alter normalized violence but may further strengthen it for those who are unable to alter their positions as their lives remain perceived and treated as ungrievable.

Some who are unable to escape the dominant discourses and power of clients, try to stage shifts to lives that are more grievable by involving stealth. Mangala who worked both as a cook and a cleaner further told us, "I don't tell anyone about my job as a cleaner but I do tell about my job as cook. My daughter is married. It will be a shameful thing if her inlaws come to know about this." She hopes that her daughter will have a better life than her which is the case with most kajer lok. And a few of them report that their children have climbed the social ladder. In some cases, marrying their daughters into less poor families becomes a vehicle for this transformation. For example, Archo married her daughter to 
a police official's son and was happy that her daughter could access a lower middle-class consumerist lifestyle. In some other cases, educating their children becomes the route for upward social migration as Malati told us,

My daughter teaches children. She doesn't have to scrape utensils at other people's houses to earn her living. And I pray to God, that she never has to do it in her entire life. It is so humiliating. I am proud that my daughter has a job that is not looked down upon by the society. She has a job that is honored by the society. She herself is respected by the society... That is why I have been telling my younger daughter to continue her studies, so she can do something that is respectable and not frowned upon by the society.

Malati and Archo consider their work humiliating and are ashamed of it. Most kajer lok do not want their daughters to end up as domestic service providers and they would like to see their children pursuing other more respectable professions. Malati is proud of her daughter's achievement and sees vicarious social mobility through her. As opposed to her, Malati suggests that her daughter is treated with dignity because she is a teacher. In the dominant normative order, manual labor is considered inferior and a teacher is considered exalted. Despite acknowledging the precarity of the lives they live, kajer lok such as Archo and Malati do not engage in a critique of caste, class, and patriarchy and resulting consumption through which their precarity is made possible because they lack the societal support and the means to do so (Jain 2015). In addition, several kajer lok report that helping their children to climb the social ladder makes them more exposed to the market as they usually need to take out loans for their children in order to be able to invest in them. Archo took loans from many of her middle-class clients to pay the dowry for her daughter's wedding. Similarly, Leela told us,

I have taken loans from people for my daughter's marriage. I have a huge debt to clear. I don't feel good thinking about all these, but what can I do, I had to get my daughter married, I couldn't let her sit at home at her age. Whatever money I could borrow, I borrowed and got my daughter married. Now the headache is how I need to return the money I borrowed.

Hence, while some possibilities exist for the children of kajer lok to socially migrate upwards through education or marriage such moves often come with a price for kajer lok themselves. They become even more dependent on the market, in particular on people providing loans, which can push them further into the abyss of debt and subordination (Dickey 2016; International Labor Organization 2015).

Moreover, clients are not homogenously exploitative. Some are considered kind and less exploitative by kajer lok.
Although these clients do not recognize kajer lok as equal subjects, they apprehend them as lives that count (Butler 2009). Such clients support for kajer lok through financial help, healthcare support, and everyday acts of kindness. However, these clients do not question the social norms that contribute to making the lives of kajer lok less worthy (Butler 2005). Moreover, in identifying kajer lok as vulnerable and in need of their support, such clients shore up their privileges further through paternalistic behaviors of kindness. In a way, as Butler (2014) warns, by claiming to be vulnerable kajer lok strengthen paternalistic power of clients.

Our findings also suggest that the kindness and support that clients show toward kajer lok stem from an instrumental motive, something that we were informed about when we asked kajer lok and clients how they handled situations of illness. Some kajer lok said that when they got sick, clients took care of them by either giving them money to buy medicines or taking them to physicians. Shuki told us that when she gets sick,

The lady (client) acts as if that's the end of the world. First, she takes me to the doctor. She takes a leave from her job and stays with me and makes me do exactly as the doctor advices. If I ever fall sick, I am usually fit by a couple of days due to the care that the family bestows on me.

While we do not rule out kindness, such acts of support are often triggered by the dependence of clients on kajer lok. Clients referred to the market situation arguing that while a surplus supply of kajer lok exists, it is difficult to find a kajer lok who is good and trustworthy. Therefore, clients argue that it is important to protect the investment they have made in their kajer lok. Hence, although Shuki to some extent is acknowledged as a subject in the kinder frames of recognition she refers to, this recognition is rarely as an equal being (Butler 2005b). Karabi, a 72-year-old homemaker informed us why she took good care of her kajer lok:

How can I find a maid as honest as she is? Many kajer lok have worked in my house. Some used to steal. But she is very trustworthy. Besides, nowadays it is very difficult to find a full-time maid.

For Karbi and other clients instrumental and market-based reasons shaped the display of kindness and support toward their kajer lok in situations of need. Hence, these clients do not engage in a social critique of the dominant norms. Such a critique of norms could undermine the position of power that these norms grant to consumers of domestic service. In addition, clients seem to be lacking the kind of reflexivity that such a critique is dependent on (Butler 2005). Some kajer lok saw through this instrumental kindness of clients. For example, Malati, a widow of age 35 and a mother of two daughters and one son between 20 and 15 years old, told us, 
Nobody usually uses any harsh words with me and are very polite in their behavior toward me. But I am not stupid. I understand that they actually patronize me with their smooth talk and calm behavior. That they actually point out to me by such polite behavior that they are above me in the social hierarchy, and would never have spoken to me if they hadn't had this need of me. These aspects of behavior by these people actually want to make me scream.

Hence, Malati sees maids such as her serving as a necessary evil for clients-the clients cannot live without her as they do not want to clean their dishes and do other demeaning work. In most cases, clients would like to keep kajer lok at a distance and not let their polluting influence inside their houses without such a necessity. For instance, a client contemptuously told us how he hates to see his kajer lok inside his kitchen and prefers to pay her money to go outside to eat her lunch. Hence, this apparent act of kindness of giving her money for a meal is laced with discrimination and exclusion that the normative order allows. Dickey (2000a) and Ray and Qayum (2009) emphasize that part of the historic decline of kindness and authority is due to the commercialization of servant relationships and shifting from male employment for life to female employment 'part time' in multiple households as the middle class move into high rises without maid's quarters. Even when kindness is extended and servants are treated as family members, Dickey (2000a) found that employers who extended such kindness worried that they were being exploited by servants, who took advantage and asked for more.

In summary, kajer lok witness multiple forms of normative violence and ungrievability as a result of being located in a status hierarchy in which social distinctions are premised upon violent exploitation. Some service providers offer resistance and try to make their lives more grievable. While the findings suggest that some kajer lok or their children have advanced on the social ladder and that some clients apprehend their lives and treat kajer lok with kindness, we do not find clients or service providers engaging in a reflexive critique of the norms that foster violent exploitation. The frames of recognition of grievable and ungrievable remain entrenched with some kajer lok hoping to escape without altering the coordinates of the normative framework with a reflexive critique.

\section{Discussion}

Violent exploitation of any form is shunned as unethical in contemporary societies and yet it is ubiquitous (Sample 2003). However, writings on social distinctions and status hierarchies in consumer research have paid limited attention to exploitation (e.g., Holt 1998; Üstüner and Holt 2010). Several business ethics scholars have debated its moral permissiveness in the context of exploitative sweatshop labor practices (Arnold and Bowie 2003; Preiss 2014; Snyder 2008). We have examined the issue of violent exploitation of domestic service providers by higher status clients through the lens of normative violence and grievability (Butler 2004a, 2009). Our research helps to expand the compass of research on social distinctions and exploitation in consumer ethics in several important ways by paying attention to normalization of violent exploitation through consumption.

\section{Social Distinctions and the Production of Ungrievability}

Our findings help to reveal several limitations in the consumer research devoted to social distinctions and status hierarchies that have been informed by Bourdieu's work. Unlike Bourdieusian analyses of the role of symbolic power in consumption that pay limited attention to violent exploitation and moral aspects, our critical inquiry into grievability and normative violence helps us to understand how clients and service providers reiterate a set of social distinctions through which the ungrievability of kajer lok is created. Our findings demonstrate that social distinctions do not merely manifest in status contests in which symbolic power is at stake as uncovered by Holt (1998), Üstüner and Holt (2010) and Vikas et al. (2015). Instead, we find that social distinctions produce violent exploitation that leads to the production of ungrievable lives. These ungrievable lives are not only created because of certain norms of distinction but also because these norms delimit and seemingly elevate livable lives through exclusions and ellipses. Thus, norms both create subjects and objects as well as contribute to the derealization of the kajer lok who are dehumanized and relegated to object status, which implies that violence may be inflicted against them without ethical dilemmas (Butler 2004b). We do not see violent exploitation as an individual act of moral depravity. Instead, we follow Butler (2004b, p. 16) who asks "what kind of world gives rise to such individuals? And what is the process of 'giving rise'?" Our attention to norms and anxiety-provoked heightened boundary maintenance keeps our focus firmly on social processes that contribute to violent exploitation without reducing them to individual actions.

We make several specific contributions to prior research on status consumption. We elaborate on Üstüner and Thompson's (2012) study of Turkish hair salons in which they found that the hairdressers and their higher status customers were involved in an omnidirectional status game manifested in subtle power struggles over contested forms of symbolic capital (Bourdieu 1990). We witness naked forms of physical violence and exploitation, and found that physical violence and exploitation are unidirectional; it is elite clients 
who inflict it on subordinate service providers. We also found that clients in most cases were recognized by kajer lok as wrong and unjust, and therefore as lacking in symbolic power. The physical violence and exploitation were not used because of deficit of symbolic power (cf. Burawoy 2010) but were the very practices that robbed the elite clients of symbolic capital. Further, we add to Bourdieusian analysis of symbolic power by pointing to how vulnerability has to be understood at a deeper level. For example, while Vikas et al. (2015) provide a reading of caste-based hierarchy and status contests in India, they inadequately problematize the issue of vulnerability. Drawing upon Butler, we point to how there is a contest by the elite to appropriate and exploit vulnerability in order to buttress their social positions. We show that the "pure" upper castes, and not just the "polluted" lower castes, classify themselves as vulnerable (Douglas 1966). However, unlike kajer lok, clients classify themselves as vulnerable but unpolluted, and therefore not subject to violation or classification as ungrievable. As a result, it is not only taste but also vulnerability that classifies the classifier, and contributes to violent exploitation.

We further add to the understanding of consumer hierarchy by showing how consumers derealize (Butler 2004a, 2009) kajer lok by precluding them from attaining any equality or consume spaces and objects they have access to within the household. Although some clients choose to be kind and helpful toward their kajer lok, in most cases they treat service providers as ungrievable lives. A comparison might be made to masters and slaves in the old American South. Since slaves were chattel property in the antebellum South, it is easy to imagine that they were regarded as little more than objects, totally subservient to their subject masters who dominated them with whips, laws, and other instruments of power. While power was clearly imbalanced in favor of the masters, a new line of research reveals that in many cases slaves were empowered by acting as agentic consumers more than is commonly thought (Hilliard 2014). As part of their management strategies, many plantation owners gave slaves money or the ability to earn it through doing extra work or raising crops of their own, as well as the freedom to spend this income. Such incentives were seen as a way to reward productivity, appease rebelliousness, and impress white neighbors, much as Veblen (1899) saw robber barons vicariously consuming through their wives and children.

For slaves, spending on luxuries such as clothing, better food, liquor, and other "trifles," was a means of not only of acquiring greater status, dignity, and pleasure. It also offered them "if not freedom outright, then at least markers of it" (Hilliard 2014, p. 11). In this way, the cash economy and consumer culture among slaves brought them a measure of agency, hope, local status, empowerment, and even resistance (Egerton 2006). To be sure their status as slaves placed limits on their consumer empowerment and their spending on luxuries including alcohol and gambling was often the subject of criticism by whites (Hilliard 2014). But the greatest threat perceived by masters and onlookers was perhaps the spectacle, in the words of one newspaper editorial, of "negroes ... sporting their fine Havanas and twirling their fancy canes on the side walks... parading the principal thoroughfares of the city and acting as Beau Brummel to perfection" (Hilliard 2014, p. 24). Postcolonial equivalents are seen in the elegant and fashionable clothing of the poor but impeccably dressed sappeurs in the Congo (Friedman 1990, 1991) and the bluffeurs in Côte d'Ivoire (Newell 2012, 2013). Sometimes such behavior infuriates those in higher social classes and is outlawed by sumptuary laws or punished.

In India, female servants, "must not wear clothing that is too similar to their employers' in type, fabric, color, or manner of wearing; if they do, employers may become nervous about the reduction of class distance" (Dickey 2000b, p. 479). The boundaries between clients and kajer lok are not unlike those between masters and slaves (Harju 2017). We found that subservient "objects" threaten to become dominant "subjects" if their consumption appears to be too much like their masters. Unequal consumption becomes necessary to derealize service providers and to violently extract value from them. As with Dickey (2000b), Mattila (2011), and Ray and Qayum (2009) in other parts of India, boundaries were most often cast in terms of symbolic pollution and fears that the "dirty' maids would contaminate the client's "clean" home, possessions, furnishings, food, and persons. There is a cultural heritage to these purity notions, which informs consumption and creates a dynamic status environment that contributes to making these boundaries even more important. As with physical and sexual violence, such means of emphasizing and expressing hierarchal distinctions are justified through this demeaning discourse. Hence, our focus on normative violence of segregation casts into high relief the role of derealization and creation of ungrievable lives in explaining unethical consumer behavior.

Summing up, we make an important addition to Bourdieusian reading of social distinctions in consumer research. Unlike status contests in terms of imitations and conspicuous consumption, we see something far more morally repugnant in the maintenance of social distinctions. We point to how distinctions are marked by the creation of ungrievable lives who can be violently exploited by clients. Our analysis helps to broaden the understandings of distinctions, hierarchies, symbolic power, and vulnerability.

\section{Violent Exploitation of Ungrievable Lives}

Business ethics scholars examining exploitation have debated what constitutes as exploitation and its moral 
permissibility (Arnold and Bowie 2003; Powell and Zwolinski 2012; Preiss 2014; Snyder 2008). While some researchers have rightly challenged the neglect of the exploitee's "background injustice" that entails the "structural, historical or institutional backdrop" (Preiss 2014, p. 61), we point to another missing piece in the analysis. We address the elided question of how violent exploitation relies on and engenders moral permissibility in a society that otherwise shuns violence. Butler (2004b) observes that lives that are not recognized as grievable can be exploited with impunity because in the dominant norms they do not count as humans. We found that the dominant norms of consumption at the intersection of class, caste, gender, and markets create frames of recognition that do not recognize kajer lok as grievable lives. In other words, we draw attention to how violent exploitation is normalized against those actors whose lives are made ungrievable through norms of consumption. We contribute to business ethics by showing that normative violence turns the service arena into a setting in which violent exploitation of kajer lok becomes permanent rather than temporary, the norm rather than the exception. In such settings, kajer lok get confined, dishonored, and violated. Moreover, exploitation and coercion unfold in a state of ellipsis, in which the media and law enforcement agencies maintain silence and do not take responsibility for the plight of ungrievable lives (Butler 2004b, 2009). We further point to how there is a refusal by clients to take responsibility for the ungrievable lives that their consumption creates. Therefore, shared grievability and taking responsibility become important pre-conditions for ethical behavior.

While pointing to the role of normalization of violent exploitation, we do not read norms as foreclosing possibilities of resistance and different subjectivities. In fact, we see violence as both a condition created by norms and their limits. As Butler (2009, p. 7) observes, "Production [of subjects] is partial and is, indeed, perpetually haunted by its ontologically uncertain double. Indeed, every normative instance is shadowed by its own failure, and very often that failure assumes a figural form." We witness such resistance in the refusal of kajer lok to accept their status as ungrievable lives. Furthermore, we found that some clients apprehend lives of kajer lok and show kindness toward them. However, our research further suggests why it is difficult to alter violent exploitation in a state of normalization. For instance, we found that clients' kindness is often instrumental in nature. Indeed, we find little evidence that clients recognize kajer lok as equal beings, engage in a social critique of the norms that privilege them or reflexively question their own positions. Similarly, kajer lok offer resistance by trying to become recognized by further reinforcing the dominant frames of recognition. But both kajer lok and clients fail to subvert the frames of recognition of grievability. The courage to do so, as Butler (2005; see also Loacker and Muhr
2009) suggests, is a precondition for taking responsibility and engage in ethical behavior. Taking responsibility for Butler (2005) is to realize that none of us is fully bounded or separate, but, rather, that we are at each other's mercy and inter-dependent. It is evident that to be critical of norms is not easy because it involves a critique of oneself. We do not see reflexive rupturing of the normative fabric that normalizes violent exploitation either by kinder clients or stronger kajer lok. Instead, we witness attempts to create situations of individual amelioration by kajer lok with imaginations of their children graduating to less exploitative work and by clients through small acts of benevolence. These shifts however do not alter the conditions of violent exploitation for those kajer lok who are unable to either find benevolent clients or graduate to more grievable lives. Hence, our paper elaborates on previous works in business ethics (Huber and Munro 2014; Loacker and Muhr 2009) that have drawn on Butler's ethics and contributes to writings on exploitation by shedding light on how critiquing norms and taking responsibility become paramount for moral conduct.

Beyond the issue of background conditions of injustice such as class, caste, and patriarchy that contribute to exploitation (Preiss 2014; Sample 2003), we point to the role of everyday consumption. The creation of ungrievable lives is not static and consumers and service providers are not its passive participants. These norms have to be enacted with regularity in order to persist (Butler 2004a). Everyday consuming/serving activities reinforce market-, caste- class- and patriarchy-based scripts that lead to the derealization of kajer lok. Much of the debate on exploitation in business ethics has been confined to the domain of production of goods and has overlooked the role of consumers and consumption (cf. Arnold and Bowie 2003; Preiss 2014; Snyder 2008, 2010). In under-examining exploitation in consumption, scholars have overlooked how exploitation becomes normalized part of the everyday existence of people and gets encoded into social orders. We also cast in high relief the violent exploitation of women that is encoded in domestic social orders. We point to how patriarchy creates specific conditions of moral permissibility of violent exploitation that cannot be explained through current discussions of sweatshop workers. The violence we uncover against women service providers shows that the current androcentric notions of choice and respect force women to bear exploitation in a state of ellipsis (see also Varman et al. 2018). While organized male workers in the domain of production are more frequently written about in the debates about sweatshop exploitation (Arnold and Bowie 2003; Preiss 2014; Snyder 2008, 2010), we draw attention to ellipses and denial of the right to be a speaking subject as additional conditions of the exploitation of women in the domestic sphere of consumption.

Our analysis also informs the conversation on ethical consumption in another important manner (Devinney et al. 
2010). Scholars have pointed to how the physical distance between the domains of production and consumption often leads to unethical consumer behavior (Carrington and Chatzidakis 2018). Consumer activism seeks to create more awareness among consumers, albeit limited to upper/middle classes in the Global North, to overcome the distance and to create ethical consumption (Cotte and Remi 2009; Humphrey 2016; Luetchford 2016; McEwan et al. 2015; Soper 2016). We further add to this line of analysis by showcasing the present consumers as exploitative and violent actors and how, in the words of Sorell $(1994$, p. 914), "consumers... sustain markets that are morally questionable." We argue that the problem is not of physical distance, concealment or a consumer's inability to see exploitative practices. Instead, the problem is due to the frames of recognition of grievability that are created and recreated by normative violence in consumer markets. Therefore, there is a need to develop a deeper understanding of how normative violence creates ungreivable lives.

\section{Conclusions}

In conclusion, this study offers insights into normative violence and ethics of grievability. In uncovering the normative violence faced by kajer lok we help the field of consumer research to broaden its understanding of exploitation that involves unequal clients and service providers in the domestic sphere. We conducted this work in Kolkata. Several reports (e.g., International Labor Organization 2015, 2017) and academic writings show that violent exploitation of domestic workers is widespread not only in India (Fernandes 2006, 2011) but also in many other countries (e.g., Choon-Piew 2007; Corbin 1986; Dinzey-Flores 2013; Meillassoux 1984). Exploitative domestic service exists in the affluent economies of Dubai, Riyadh, London, Los Angeles, and New York as service workers migrate in search of a better life for their families (Hochschild 2004; Ray and Qayum 2009). Therefore, the issues of social distinctions, status hierarchy, ungrievability, and normalization of violent exploitation that we identify are likely to be of relevance to such settings of domestic work elsewhere. However, we note, by borrowing from Thompson and Arsel (2004, p. 640), that, "our analysis follows in the logic of the interpretive case method, which offers a means to advance theoretical arguments without making universalizing claims.” Thus, we do not foreclose other possibilities of domestic work in different parts of India and outside.

The violent exploitation of kajer lok is a structural condition and not based on individual propensities of some clients. While our findings show that some kajer lok offer resistance through infra-politics and that some clients are more kind and benevolent, these interventions offer only a limited amelioration from violent exploitation. Therefore, a structural transformation is needed to restrict or put an end to violence. Such a transformation will require collective mobilizations through unionization and other civil society interventions. In different parts of India, there are attempts to organize domestic workers to overcome violent exploitation. For example, Rajasthan Mahila Kamgaar Union (RMKU) based in Jaipur has more than 12,000 domestic workers as members, who are collectively fighting for their rights (Shukla 2016). However, a key to the success of these working-class politics is going to be in transforming structural conditions that give rise to ungrievability without falling in the trap of NGO-based middle-class kindness and benevolence that are displayed by some clients, which may only exacerbate and legitimize violent exploitation.

Future studies can examine different modes of resistance to violent exploitation. It is important to understand various attempts by the vulnerable to create livable lives and grievability. These studies can also examine various technologies that both further and subvert frames of recognition of grievability. In addition, future research can offer insights into market mechanisms that help to limit ungrievability and what policy frameworks can strengthen such modalities. Such studies are necessary not only for furthering consumer ethics but also for deepening our understanding of social distinctions, vulnerability, exploitation, and grievability.

\section{Compliance with Ethical Standards}

Conflict of interest Rohit Varman, Per Skålén, Russell W. Belk, and Himadri Roy Chaudhuri declare that they have no conflicts of interest.

Ethical Approval All procedures performed in studies involving human participants were in accordance with the ethical standards of the institutional and/or national research committee and with the 1964 Helsinki declaration and its later amendments or comparable ethical standards.

Informed Consent Informed consent was obtained from all individual participants included in the study.

Open Access This article is licensed under a Creative Commons Attribution 4.0 International License, which permits use, sharing, adaptation, distribution and reproduction in any medium or format, as long as you give appropriate credit to the original author(s) and the source, provide a link to the Creative Commons licence, and indicate if changes were made. The images or other third party material in this article are included in the article's Creative Commons licence, unless indicated otherwise in a credit line to the material. If material is not included in the article's Creative Commons licence and your intended use is not permitted by statutory regulation or exceeds the permitted use, you will need to obtain permission directly from the copyright holder. To view a copy of this licence, visit http://creativecommons.org/licenses/by/4.0/. 


\section{References}

Allen, D. E. (2002). Toward a theory of consumer choice as sociohistorically shaped practical experience: The fits-like-a-glove (FLAG) framework. Journal of Consumer Research, 28(4), 515-532.

Arnold, D. G., \& Bowie, N. E. (2003). Sweatshops and respect for persons. Business Ethics Quarterly, 13(2), 221-242.

Arnold, D. G., \& Bowie, N. E. (2007). Respect for workers in global supply chains: Advancing the debate over sweatshops. Business Ethics Quarterly, 17(1), 135-145.

Arnold, D. G., \& Hartman, L. P. (2003). Moral imagination and the future of sweatshops. Business and Society Review, 108(4), 425-461.

Arnold, D. G., \& Hartman, L. P. (2006). Worker rights and low wage industrialization: How to avoid sweatshops. Human Rights Quarterly, 28, 676-700.

Bales, K., Trodd, Z., \& Willamson, A. K. (2009). Modern slavery: The secret world of 27 million people. Oxford: Oneworld Publishers.

Baviskar, A., \& Ray, R. (Eds.). (2015). Elite and everyman: The cultural politics of Indian middle classes. New Delhi: Routledge India.

Béteille, A. (1996). Caste, class and power: Changing patterns of stratification in a Tanjore village. New Delhi: Oxford University Press.

Bourdieu, P. (1984). Distinction: A social critique of the judgement of taste. London: Routledge.

Bourdieu, P. (1977). Outline of a theory of practice. Cambridge: Cambridge University Press.

Bourdieu, P. (1990). The logic of practice. Stanford, CA: Stanford University Press.

Burawoy, M. (2010) Gentle violence, brutal violence and the struggle to empower women. Retrieved October 28, 2019, from https:// burawoy.berkeley.edu/Bourdieu/KVH7.pdf.

Butler, J. (2004a). Undoing gender. New York: Routledge.

Butler, J. (2004b). Precarious life: The powers of mourning and violence. London: Verso.

Butler, J. (2005). Giving an account of oneself. Oxford: Oxford University Press.

Butler, J. (2009). Frames of war: When is life grievable?. London: Verso.

Butler, J. (2014). Rethinking vulnerability and resistance. Retrieved September 9, 2019, from https://www.institutofranklin.net/sites /default/files/files/Rethinking\%20Vulnerability\%20and\%20Res istance\%20Judith\%20Butler.pdf.

Carrington, M., \& Chatzidakis, A. (2018). Critical perspectives on ethical consumption. In Routledge companion to critical marketing. London: Routledge.

Chakravarty, D., \& Chakravarty, I. (2008). Girl children in the care economy: Domestics in West Bengal. Economic \& Political Weekly, 43(48), 93-100.

Chen, A. M. (2012). The informal economy: Definitions, theories and policies. Working paper no. 1. Manchester: Women in Informal Employment: Globalising and Organising (WIEGO)

Choon-Piew, P. (2007). Gated communities in China. London: Routledge.

Corbin, A. (1986). The foul and the fragrant: Odor and the French imagination. Cambridge, MA: Harvard University Press.

Cotte, J., \& Remi, T. (2009). Does it pay to be good? MIT Sloan Management Review, 50(2), 61-68.

Devinney, T. M., Auger, P., \& Eckhardt, G. (2010). The myth of the ethical consumer. Cambridge, UK: Cambridge University Press.

Dickey, S. (2000a). Mutual exclusions: Domestic workers and employers on labor, cless, and character in South India. In K. Adams \&
S. Dickey (Eds.), Home and hegemony: Domestic service and identity politics in South and Southeast Asia (pp. 31-61). Ann Arbor: University of Michigan Press.

Dickey, S. (2000b). Permeable homes: Domestic service, household space, and the vulnerability of class boundaries in urban India. American Ethnologist, 27(2), 462-489.

Dickey, S. (2016). Living class in urban India. New Brunswick, NJ: Rutgers University Press.

Dinzey-Flores, Z. (2013). Locked in, locked out: Gated communities in a Puerto Rican City. Philadelphia, PA: University of Pennsylvania Press.

Douglas, M. (1966). Purity and danger. London: Routledge and Keegan Paul.

Dumont, L. (1970). Homo hierarchicus: An essay on the caste system. Translated (From the French) by Mark Sainsbury.

Dutt, A. (2018). Locating patriarchy in violence against women in India: Social, legal and alternative responses. People: International Journal of Social Sciences, 4, 212-228.

Egerton, D. R. (2006). Slaves to the marketplace: Economic liberty and black rebelliousness in the Atlantic world. Journal of the Early Republic, 26(4), 617-639.

Evans, B., \& Giroux, H. A. (2015). Disposable futures: The seduction of violence in the age of spectacle. New York: City Lights Publishers.

Fernandes, L. (2006). India's new middle class: Democratic politics in an era of economic reform. Minneapolis, MN: University of Minnesota Press.

Fernandes, L. (2011). Hegemon and inequality: Theoretical reflections of India's middle class. In A. Baviskar \& R. Ray (Eds.), Elite and everyman: The cultural politics of the Indian middle class (pp. 58-82). New Delhi: Sage.

Fontaine, L. (2015). The moral economy: Poverty, credit, and trust in early modern Europe. New York: Cambridge University Press.

Friedman, J. (1990). The political economy of elegance: An African cult of beauty. Culture and History, 7, 101-125.

Friedman, J. (1991). Consuming desires: Strategies of selfhood and appropriation. Cultural Anthropology, 6(2), 154-163.

Froystad, K. (2005). Blended boundaries. Caste, class, and shifting faces of 'hinduness' in a north Indian City. Delhi: Oxford University Press.

Gadamer, H. G. (2004). Truth and method. London: Continuum.

Galtung, J. (1990). Cultural violence. Journal of Peace Research, 27(3), 291-305.

Gettman, H. J., \& Gelfand, M. J. (2007). When the customer shouldn't be king: Antecedents and consequences of sexual harassment by clients and customers. Journal of Applied Psychology, 92(3), 757.

Gubler, J. R., Herrick, S., Price, R. A., \& Wood, D. A. (2018). Violence, aggression, and ethics: the link between exposure to human violence and unethical behavior. Journal of Business Ethics, 147(1), 25-34.

Gupta, D. (1991). Hierarchy and difference: An introduction. In D. Gupta (Ed.), Social stratification (pp. 1-22). New Delhi: Oxford University Press.

Harju, O. (2017). Women and maids: Perceptions of domestic workers, housework and class among young, progressive, middle- to upper-class women in Delhi. Working papers in contemporary Asian studies no. 55. Lund: Centre for East and South-East Asian Studies, Lund University. Retrieved August 8, 2019, from https:// portal.research.lu.se/portal/files/33298179/Otso_Harju_WP201 7.pdf.

Hilliard, K. (2014). Masters, slaves, and exchange: Power's purchase in the old south. Cambridge: Cambridge University Press.

Hochschild, A. (2004). Love and gold. In B. Eherenreich \& A. Hochschild (Eds.), Global woman: Nannies, maids, and sex workers in the new economy (pp. 15-30). New York: Henry Holt. 
Holt, D. B. (1998). Does cultural capital structure American consumption? Journal of Consumer Research, 25(1), 1-25.

Huber, C., \& Munro, I. (2014). "Moral distance" in organizations: An inquiry into ethical violence in the works of Kafka. Journal of Business Ethics, 124(2), 259-269.

Humphrey, K. (2016). Buying a better world. In D. Shaw, A. Chatzidakis, \& M. Carrington (Eds.), Ethics and morality in consumption: Interdisciplinary perspectives (pp. 138-152). London: Routledge.

Ignatow, G. (2009). Why the sociology of morality needs Bourdieu's habitus. Sociological Inquiry, 79(1), 98-114.

International Labor Organization. (2015). Indispensable yet unprotected: Working conditions of Indian domestic workers at home and abroad. Geneva: International Labour Office, Fundamental Principles and Rights at Work Branch.

International Labor Organization. (2017). Global estimates of modern slavery: Forced labour and forced marriage. Geneva: ILO.

Jaffe, R., \& Dürr, E. (2010). Introduction: Cultural and material forms of urban pollution. In E. Dürr \& R. Jaffe (Eds.), Urban pollution: Cultural meanings, social practices (pp. 1-29). New York: Berghahn.

Jain, M. (2015) This online company provides maids-And lets you pick them by religion and region. Scroll.in. Retrieved October 28, 2019, from https://scroll.in/article/766490/this-onlin e-company-provides-maids-and-lets-you-pick-them-by-relig ion-and-region.

Joy, A., Belk, R. W., \& Bhardwaj, R. (2015). Judith butler on gender performativity and precarity: Exploratory thoughts on gender and violence in India. Journal of Marketing Management, 31(15-16), $1739-1745$

Karhu, S. (2017). From violence to resistance: Judith butler's critique of norms. Retrieved October 28, 2019, from https://helda.helsi nki.fi/handle/10138/222477?locale-attribute=en.

Kumari, M. (1989). Patriarchy and violence against women in India. In N. Sinha (Ed.), Women and violence. New Delhi: Vikas Publishing House.

Loacker, B., \& Muhr, S. L. (2009). How can I become a responsible subject? Towards a practice-based ethics of responsiveness. Journal of Business Ethics, 90(2), 265.

Lokesh, (2015). Making the personal political: The first domestic workers strike in Pune, Maharashtra. In D. Hoerder, E. NederveenMeerkerk, \& S. Neunsinger (Eds.), Towards a global history of domestic and caregiving workers (pp. 202-221). Brill: Leiden.

Luetchford, P. (2016). market, society and morality: towards an anthropology of ethical consumption. In D. Shaw, A. Chatzidakis, \& M. Carrington (Eds.), Ethics, morality and consumption: Interdisciplinary perspectives: Routledge studies in business ethics (pp. 153-170). London: Routledge.

Manusmriti. (Undated). Manusmriti: Law book of Hindus. Retrieved October 28, 2019, from https://www.angelfire.com/ak/ambedkar/ BRManusmriti.html.

Mattila, P. (2011). Domestic labour relations in India-Vulnerability and gendered life courses in Jaipur. Helsinki: Institute of Development Studies, University of Helsinki. Retrieved August 8, 2019, from https://core.ac.uk/download/pdf/14921751.pdf.

McCracken, G. (1988). The long interview. London: Sage.

McEwan, C., Hughes, A., \& Bek, D. (2015). Theorising middle class consumption from the global south: A study of everyday ethics in South Africa's Western Cape. Geoforum, 67, 233-243.

Meillassoux, C. (1984). Maidens, meal and money: Capitalism and the domestic community. Cambridge: Cambridge University Press.

Menon, N. (2012). Seeing like a feminist. London: Penguin UK.

Mitra, A. (2005). Women in the urban informal sector: Perpetuation of meagre earnings. Development and Change, 36(2), 291-316.

Namala, A. (2016). Violence against Dalits: There is a discernable pattern to this madness. Retrieved January 19, 2017, from https:// indianexpress.com/article/blogs/dalit-violence-gujarat-gau-raksh aks-2930876/.

Newell, S. (2012). The modernity bluff: Crime, consumption, and citizenship in Côte d'Ivoire. Chicago, IL: University of Chicago Press.

Newell, S. (2013). Brands as masks: Public secrecy and the counterfeit in Côte d'Ivoire. Journal of the Royal Anthropological Institute, $19,138-154$.

Powell, B., \& Zwolinski, M. (2012). The ethical and economic case against sweatshop labor: A critical assessment. Journal of Business Ethics, 107(4), 449-472.

Preiss, J. (2014). Global labor justice and the limits of economic analysis. Business Ethics Quarterly, 24(1), 55-83.

Raghuram, P. (1993). Invisible female agricultural labour in India. In V. Kinnaird \& J. Momsen (Eds.), Different places, different voices: Gender and development in Africa, Asia and Latin America (pp. 109-119). London, UK: Routledge.

Raghuram, P. (2001). Caste and gender in the organisation of paid domestic work in India. Work, Employment and Society, 15(3), 607-617.

Raghuram, P. (2005). Global maid trade: Indian domestic workers in the global market. In S. Huang, N. Abdul Rahman, \& B. Yeoh (Eds.), Asian transnational domestic workers. Singapore: Marshall Cavendish.

Ray, R., \& Qayum, S. (2009). Cultures of servitude: Modernity, domesticity, and class in India. Stanford, CA: Stanford University Press.

Sample, R. J. (2003). Exploitation: What it is and why it's wrong. Lanham, MD: Rowman \& Littlefield.

Sayer, A. (2005). The moral significance of class. Cambridge: Cambridge University Press.

Shukla, A. (2016) The life of domestic workers in India. And the ray of hope. Retrieved October 28, 2019, from https://www.thebe tterindia.com/42646/domestic-workers-jaipur-mewa-bharti-rajas than-mahila-kamgaar-union/.

Snyder, J. C. (2008). Needs exploitation. Ethical Theory and Moral Practice, 11(4), 389-405.

Snyder, J. C. (2010). Exploitation and sweatshop labor: Perspectives and issues. Business Ethics Quarterly, 20(2), 187-213.

Soper, K. (2016). Towards a sustainable flourishing: Ethical consumption and the politics of prosperity. In D. C. Shaw, A. Chatzidakis, \& M. Carrington (Eds.), Ethics and morality in consumption. Interdisciplinary perspectives (pp. 43-59). London: Routledge.

Sorell, T. (1994). The customer is not always right. Journal of Business Ethics, 13(11), 913-918.

Swartz, D. (1997). Culture and power: The sociology of Pierre Bourdieu. Chicago: University of Chicago Press.

Tellis-Nayak, V. (1983). Power and solidarity: Clientage in domestic service. Current Anthropology, 24, 67-79.

Teltumbde, A. (2010). The persistence of caste: The Khairlanji murders and India's hidden apartheid. London: Zed Books.

Thompson, C. J., \& Arsel, Z. (2004). The starbucks brandscape and consumers' (Anticorporate) experiences of glocalization. Journal of Consumer Research, 31(3), 631-642.

Unni, J. (2001). Gender and informality in the labour market in South Asia. Economic \& Political Weekly, 36(26), 2360-2377.

Üstüner, T., \& Holt, D. B. (2007). Dominated consumer acculturation: The social construction of poor migrant women's consumer identity projects in a Turkish squatter. Journal of Consumer Research, 34(1), 41-56.

Üstüner, T., \& Holt, D. B. (2010). Toward a theory of status consumption in less industrialized countries. Journal of Consumer Research, 37(1), 37-56.

Üstüner, T., \& Thompson, C. J. (2012). How marketplace performances produce interdependent status games and contested 
forms of symbolic capital. Journal of Consumer Research, 38(5), 796-814.

Valdman, M. (2008). Exploitation and injustice. Social Theory and Practice, 34(4), 551-572.

Varman, R., Skålén, P., \& Belk, R. W. (2012). Conflicts at the bottom of the pyramid: Profitability, poverty alleviation, and neoliberal governmentality. Journal of Public Policy and Marketing, 31(1), 19-35.

Varman, R., Goswami, P., \& Vijay, D. (2018). The precarity of respectable consumption: normalising sexual violence against women. Journal of Marketing Management, 34(11-12), 932-964.

Veblen, T. (1899). The theory of the leisure class: An economic study of institutions. New York: Macmillan.

Vikas, R. M., Varman, R., \& Belk, R. W. (2015). Status, caste, and market in a changing Indian village. Journal of Consumer Research, 42(3), 472-498.
Waldrop, A. (2004). Gating and class relations: The case of a New Delhi 'colony'. City and Society, 16(2), 93-116.

Wertheimer, A. (1996). Exploitation. Princeton, NJ: Princeton University Press.

Wolff, J. (1999). Marx and exploitation. The Journal of Ethics, 3(2), $105-120$.

Zwolinski, M. (2007). Sweatshops, choice, and exploitation. Business Ethics Quarterly, 17(4), 689-727.

Publisher's Note Springer Nature remains neutral with regard to jurisdictional claims in published maps and institutional affiliations. 